\title{
Female Labor Force Participation in Vocational Village Programs
}

\author{
Malahayati Rahman ${ }^{1, *}$ \\ ${ }^{1}$ Universitas Malikussaleh \\ ${ }^{*}$ Corresponding author. Email: malahayati@unimal.ac.id
}

\begin{abstract}
This paper aims to analyze the Female Labor Force Participation (FLFP) in North Aceh District's vocational village program. We researched four vocational villages in North Aceh, namely Ulee Madon, Pande, Alue Leuhob, and Alue Capli. Researchers obtained data through surveys and structured-interviews with parties involved in implementing the village vocational program in North Aceh. The survey results were analyzed using a mixed-methods approach. The results showed that the vocational program to increase the workforce's capacity in North Aceh District had not achieved maximum results. The vocational village program's impact has not been felt directly by women workers on improving their business field skills. Of the 76 workers and business actors who became respondents, only $39.5 \%$ positively impacted training on the quality and quantity of products, business management, marketing, and especially their income. The FLFP rate explanation will be divided into program planning, training, procurement of raw materials, production, marketing, and financial management. The results showed that the FLFP rate at each stage was still shallow. The highest level of FLFP was at the planning, training, production, and the material procurement stage, while the marketing and financial management stages were still shallow. The authors concluded that the local community's social fabric regarding women's status in the family determines the level of FLFP. For this reason, FLFP mainstreaming is required based on Gender Equity and Social Inclusion (GESI) and local wisdom to increase the economic growth of rural communities.
\end{abstract}

Keywords: Gender Equity, Social Inclusion, Mainstreaming, North Aceh

\section{INTRODUCTION}

Women have an essential role in the economy and development. However, women often experience structural and social obstacles in getting the development's benefits [1]. Women have to fight harder to be involved and benefit from development than other groups in society. Family economic conditions affect the level of women's activity at work [2]. The lower the family income, the higher the woman's economic activity in meeting all family members' financial needs.

The division of work types between women and men is often linked to their power relations within the family and society. In the past, women only acted as domestic workers, and women were considered impossible to achieve the same achievements as men [3]. Nevertheless, lately, the situation has changed considerably. The level of FLFP is getting higher and impacts women and their families' economic status and the country's economic growth [4].
One of the programs to accelerate community economic growth in Indonesia is the Vocational Village Program, which is implemented under the Ministry of Education and Culture. Vocational villages are rural areas that develop various skills or vocational education services and business groups to enhance human resources capability. They can create products or services or other high economic value works, which are unique, by exploring and developing village potentials with comparative advantages, based on local wisdom [5]. Each village has a different vocational program, depending on the natural \& human resources and the market needs. North Aceh Regency has 4 (four) vocational villages that have been designated by the Ministry of National Education, namely Ulee Madon, Pande, Alue Leuhob, and Alue Capli.

North Aceh has been implementing the Vocational Village Program since 2016. However, it has not been able to increase the capacity and income of FLF positively. The implementation of the vocational village 
program faces several problems, such as the lack of skilled-trainers, distribution of products, and sustainability [6].

According to the authors' hypothesis, this obstacle cannot be separated from the lack of FLFP, and the patriarchal social order of the Aceh society has influenced the FLFP level. The level of FLFP on the vocational village program in Aceh Utara directly correlates to the program's success.

Various studies have stated that many factors influence the FLFP level [7]-[9]. Generally, the results of these studies agree that social institutions and policies influence women's attitudes. Various papers have also studied FLFP from diverse global and national perspectives, mainly focusing on comparative studies of FLFP levels between countries [10].

This paper will specifically analyze FLFP on the vocational village program based on the concept of Gender Equity and Social Inclusion (GESI), which focuses on the imbalance of power relations experienced by women in increasing their capacity in the vocational village program in North Aceh.

\section{METHODS}

The research team surveyed four vocational villages in North Aceh District, namely Pande Village, Ulee Madon Village, Alue Leuhob Village, and Alue Capli Village. The researchers surveyed for two weeks, from 14-28 September 2020. The sample selection was carried out purposively by directly visiting the samples in their respective homes.

However, the Covid-19 pandemic condition became a significant obstacle in collecting data because they still had to carry out the Health protocol. This condition impacts the number of respondents, which must be reduced significantly, from 160 Female Labor Forces (FLF) to only 76 FLF. Research questions are posed in a familiar atmosphere and carried out by surveyors familiar with the research environment. Respondents are expected to respond honestly and without bias.

The survey data is inputted in the google form. All data were then verified, clustered, coded, and described qualitatively using the NVivo application. Authors refer to the theory of gender equity and social inclusion (GESI) as a rationale for analyzing research data.

\section{RESULTS}

\subsection{Geographical Data}

Several villages were taken as samples to determine the level of FLFP in implementing the vocational village program in North Aceh. The selection of this village is based on its status as a vocational village. The villages are Ulee Madon in Muara Batu District, Pande in Tanah Pasir District, Alue Leuhob in Cot Girek District, Alue Capli, and Cot Patisah in Seunuddon District.

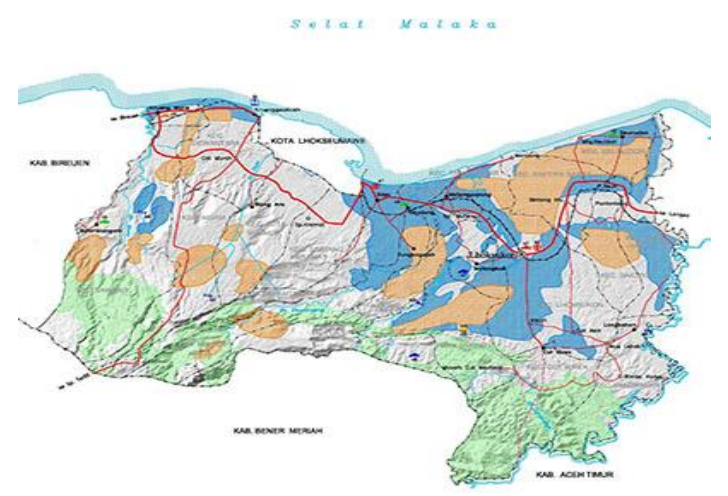

Figure 1: The Map of North Aceh

The total population of North Aceh Regency in 2019 is 619,407 people, with a composition of 306,105 men and 313,302 women. The population's average sex ratio based on the district area is 97.70, with an annual population growth rate of $2.12 \%$. It is a land area of $3,296.86 \mathrm{~km} 2$ and has 852 villages spread over 27 districts. The population density per $\mathrm{km} 2$ is 9,373 . Of the 265,708 people in the labor force, there are still 27,038 unemployed, 14,164 men, and 12,874 women, which means that the labor force participation rate is still $63.56 \%$, and the unemployment rate is $10.18 \%$. In 2019 , the self-employed workers were 53,157 or around $22.3 \%$ of the total working age.

The districts with vocational villages consist of Muara Batu District, Tanah Pasir District, Cot Girek District, and Seunuddon District. Ulee Madon (Muara Batu District) population is 1,784, consisting of 872 men and 913 women, with 373 households. There are approximately 28 types of independent businesses that are engaged in industry and trade. The number of small and home industries in weaving and traditional handicrafts are around 11 industries.

The vocational village in Tanah Pasir District is Pande Village. The total population of Pande Village in 2018 was 1,079 people, 299 households, consisting of 523 men and 556 women. The most dominant type of home industry in Pande Village is the metal goods industry, namely iron craftsmen.

Cot Girek District has one vocational village, namely Alue Leuhob Village. Alue Leuhob has an area of 13 KM2 consisting of hilly areas. The total population is 1,463 people, 451 families, consisting of 720 men and 743 women, the majority of whom are Javanese. The primary income of the household head in Alue Leuhob is agriculture $(300 \mathrm{HH})$, industry $(29 \mathrm{HH})$, trade $(24 \mathrm{HH})$, transportation, and other services (99 $\mathrm{HH})$. The most dominant home industries are tofu and Tempe production. 
Alue Capli is a vocational village in Seunuddon District, with 626 people, consisting of 316 men and 310 women. The primary income of the people of Alue Capli is agriculture. The types of small and household industries in Alue Capli are the wicker industry.

\subsection{Respondent}

The majority of respondents' education is graduates from junior high school (34.2\%), elementary school $(28.9 \%)$, general and vocational high school (23.7\%), while the rest are undergraduates $(2.6 \%)$, traditional dayah $(5.3 \%)$, and non-formal education $(5.3 \%)$. The respondents' marital status is generally married $(73.7 \%)$, while the rest are unmarried and widowed, respectively $13.2 \%$.

The income of female workers who became respondents was divided into several groups, namely:

\begin{tabular}{|c|c|c|}
\hline Range of Income & FLF & $\%$ \\
\hline Less than IDR. 1.000.000,- & 34 & 44,7 \\
\hline IDR. 1.000.001,- to IDR. 2.000.000,- & 10 & 13,2 \\
\hline IDR. 2.000.001,- to IDR. 3.000.000,- & 20 & 26,3 \\
\hline IDR. 3.000.0010,- to IDR. 4.000.000,- & 0 & 0 \\
\hline More than IDR. 4.000.001,- & 12 & 15,8 \\
\hline
\end{tabular}

Tabel 1: FLF Income in Vocational Village

The types of businesses they do are food and beverage (18.4\%), blacksmith and metal handicrafts (34.2\%), woven crafts (18.4\%), and Acehnese handicrafts $(28.9 \%)$.

\subsection{Vocational Villages \& FLFP}

The implementation of a workshop in the vocational village program is two months in each village. The types of training and mentoring programs provided are general training and not related to the FLF business sector $(29.1 \%)$, special training directly related to the business sector $(50 \%)$, product innovation training (16.7\%), and management training (4.2\%).

FLFP in the vocational village program can be divided into several stages of implementation, namely Program Planning, Training, Material Procurement, Production, Marketing, and Financial Management, as shown in the table below:

\begin{tabular}{|c|c|c|c|c|c|c|}
\hline \multirow[b]{2}{*}{ Stages } & \multicolumn{4}{|c|}{ FLFP } & \multicolumn{2}{|c|}{ Rate of FLFP } \\
\hline & 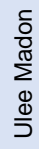 & $\begin{array}{l}\frac{0}{0} \\
\stackrel{0}{\pi} \\
\stackrel{0}{\square}\end{array}$ & $\begin{array}{l}\text { 응 } \\
\frac{1}{5} \\
\frac{1}{1} \\
\frac{0}{2} \\
\frac{0}{<}\end{array}$ & 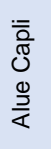 & Total & $\begin{array}{c}\% \\
(n=76)\end{array}$ \\
\hline Planning & 6 & 4 & 14 & 2 & 26 & 34.2 \\
\hline Workshop & 4 & 4 & 12 & 4 & 24 & 31.6 \\
\hline Material Procurement & 0 & 2 & 4 & 4 & 20 & 26.3 \\
\hline Production & 4 & 6 & 8 & 4 & 22 & 28.9 \\
\hline Marketing & 4 & 2 & 4 & 2 & 12 & 15.8 \\
\hline $\begin{array}{l}\text { Financial } \\
\text { Management }\end{array}$ & 0 & 2 & 12 & 0 & 14 & 18.4 \\
\hline Median & 3 & 3.3 & 9 & 2.7 & & \\
\hline
\end{tabular}

Table 2: FLFP in Vocational Program

\section{DISCUSSION}

In general, FLFs involved in vocational villages' business activities are the labor force age (14-66 yo), married, and only have junior high school education. The number of housewives who have household businesses in vocational villages depends on the type of business. They prefer jobs that can be done in their spare time and do not need to leave their homes and families. It can be seen in the types of businesses such as woven mats, Acehnese embroidery \& bag crafts, and the food/beverage industry in the vocational villages of Ulee Madon, Alue Leuhob, and Alue Capli. All of the skills required for this business are skills usually practiced by a housewife.

As for the blacksmith business in Pande, although the manufacturing process requires intense physical energy, some work aspects still require women's skills. Making product accessories and finishing requires a woman's patience so that the products produced are economically valuable and have high aesthetic value. This blacksmith business is generally a family business from generation to generation where the work location is in their yard. Thus, the role of women as housewives can still be carried out properly.

Based on these data, it can be seen that FLFP in the vocational village program is strongly influenced by cultural values or local wisdom in the local community. In general, the public view of a woman's role in Aceh is as a housewife who has the noblest task of taking care of her family. This condition is in line with the approach taken by Esping Andersen et al., which states that the FLFP level is based on several fundamental principles such as religious belief or ideology, solidarity, and equality [11]. According to him, a woman's primary consideration to participate in the work activities is a familial-cultural orientation with a specific economic structure (business sector).

This reality refutes the opinion that the main consideration of FLFP is welfare policy or income level [12]. Based on research data, it can be seen that the level of FLF income is still deficient [Table 1]. However, this condition does not make FLF leave their jobs that have been carried out for generations.

FLFP in implementing the vocational village program in Aceh Utara can be analyzed in two divisions, based on the vocational village and the stages of program implementation [Table 2].

By village division, the highest average FLFP rate occurred in Alue Leuhob village. This FLFP rate is well above the FLFP rate in other villages. Based on the authors' assumptions, this happened because it was influenced by the local community's culture and character. The majority of Alue Leuhob are Javanese, who are more open and have a strong character at work. 
Javanese's seven strengths are tenacity, creativity, perspective, justice, vitality, curiosity, and forgiveness [13].

On the other hand, the three other vocational villages whose majority population are Acehnese have different social values. The people of Aceh are very much influenced by the values of local wisdom and religion. The public view of FLF is still in its central role as housewives, glorified women, who work only as free time fillers after carrying out their primary duties as mothers or wives. This view fits perfectly with the approach presented by Esping Andersen.

Based on the stages of program implementation, relatively high levels of FLFP are found in the planning, workshop, and production stages. The explanation for this finding is that women's role is needed so that the vocational village program can be adequately implemented. Women are involved in determining the programs to be implemented at the planning stage because the prospective training program participants are women. Women become training participants because, generally, men do not like training activities. The relatively long training time ( 2 months) is also a consideration in determining the training type to be carried out. Generally, the training provided in vocational programs is a skill that can increase the productivity of FLF. This condition then affects the high FLFP at the three stages of implementing the vocational program.

On the other hand, FLFP is still relatively low at the marketing and financial management stages. It is closely related to the power relationship between a wife and husband or women and men. In Acehnese society, generally, matters related to finances are in the male hands (husband). At the marketing stage, the money from the sale and management falls under the men's authority. In this position, the power relationship between women and men becomes unbalanced. It proves the author's hypothesis about the patriarchal social order of the Acehnese society, which influences FLFP in implementing the vocational village program.

The low level of FLFP in implementing the vocational village program in North Aceh resulted in various obstacles in achieving its objectives. The training provided is not under the vocational village program's needs because it only considers the participants' time availability, not based on developing existing vocational businesses.

\section{CONCLUSION}

Based on the above discussion, we conclude that the level of FLFP in implementing the Vocational Village Program in North Aceh is still deficient because the community's patriarchal social order influences it. Even though the type of business run by FLF is still under the local community's social fabric or local wisdom, women are not yet in a policy decision-making position.

Given the importance of social order in improving FLFP in a program, the authors recommend that an FLF empowerment policy be designed based on GESI and local wisdom. This concept must make GESI values in line with the local wisdom values of the local community.

\section{AUTHOR'S CONTRIBUTIONS}

Malahayati conceived of the presented idea, wrote the manuscript, reviewed and finalised it.

\section{ACKNOWLEDGMENTS}

We thank the Regent of North Aceh (Muhammad Thaib) and the Regional Secretary of North Aceh (Abdul Aziz); for their assistance and support in data collecting. We highly appreciate all of Camat (the head of districts) and Keuchik (the head of villages) of Vocational Villages, who facilitated authors in obtaining research data.

We also thank the Research Institutions and Community Service (LPPM) of Universitas Malikussaleh and the Ministry of Research and Technology/National Research and Innovation Agency of the Republic of Indonesia for their support and funding from 2018-2020.

This research could not run well without fellow researchers; Laila M. Rasyid, Elidar Sari, Hadi Iskandar, Muhammad Nasir, Romi Asmara, Ferdy Saputra Yusrizal, Sofyan Jafar, T. Yudi A, Fauzah Nur Aksa, and students of Universitas Malikussaleh, Balqis, Dwi Mahara, Reza Fahlevi, Boy Haki, Ananda, Adelia, Aditya, Khalil, Khalib, Mustafa Kamal, Choirul Anam, Tyas, Cici, and Idolanami, who helped collect field data from 2018-2020.

\section{REFERENCES}

[1] Prisma, "Gender Equality and Social Inclusion." https://aip-prisma.or.id/en/gs-inclusion (accessed Oct. 20, 2020).

[2] Elfendri and B. Nasri, Ekonomi dan Ketenagakerjaan. Padang: Andala University Press, 2004

[3] F. Engels, "The Origin of the Family , Private Property and the State," Online, 1884.

[4] Australian Government, "An Australian Government Strategy to Boost Women's Workforce Participation: Women's Workforce Participation - an Economic Priority." https://womensworkforceparticipation.pmc.gov.au/ index.html. 
[5] Kementerian Pendidikan dan Kebudayaan Republik Indonesia, Petunjuk Teknis Bantuan Sosial Desa Vokasi. Jakarta: Kementerian Pendidikan dan Kebudayaan Republik Indonesia, 2014.

[6] M. Malahayati and L. M. Rasyid, "The Development of Vocational Village Concept Based on Local Wisdom and Inclusiveness in North Aceh," Proc. Int. Conf. Law, Gov. Islam. Soc. (ICOLGIS 2019), 2020, DOI: 10.2991/assehr.k.200306.196.

[7] G. SS, W. CMMP, V. JD, and D. S., "Women's labor force transitions in connection with childbirth: A panel data comparison between Germany, Sweden and Great Britain," Journal of Population Economics. 1996.

[8] R. Ray, J. C. Gornick, and J. Schmitt, "Who cares? assessing generosity and gender equality in parental leave policy designs in 21 countries," $J$. Eur. Soc. Policy, vol. 20, no. 3, pp. 196-216, 2010, DOI: $10.1177 / 0958928710364434$.

[9] L. Cameron, D. C. Suarez, and W. Rowell, "Female Labor Force Participation in Indonesia: Why Has it Stalled?," Bull. Indones. Econ. Stud., vol. 55, no. 2, pp. 157-192, May 2019, DOI: 10.1080/00074918.2018.1530727.

[10] P. H. Jensen, "Cause and effects of female labor force participation in local welfare systems," European Societies. 2017, DOI: 10.1080/14616696.2016.1268706.

[11] A. Hicks and G. Esping-Andersen, "The Three Worlds of Welfare Capitalism.," Contemp. Sociol., vol. 20, no. 3, p. 399, May 1991, DOI: $10.2307 / 2073705$.

[12] A. Winkler, "Women's labor force participation," IZA World Labor, 2016, DOI: 10.15185/izawol.289.

[13] H. Wijayanti and F. Nurwianti, "Kekuatan Karakter dan Kebahagiaan Pada Suku Jawa," Feb. 2010. Accessed: Oct. 20, 2020. [Online]. Available: https://ejournal.gunadarma.ac.id/index.php/psiko/a rticle/view/227. 